\title{
Dry Matter Production by Chamaecyparis pisifera in Winter
}

\author{
by Nobuo Nomoto*, Hiromi KASANAGA** and Masami Monsi*:
}

野本宣夫*・笠永博美**・門司正三**：サワラの冬に心ける物質生産

Received July 23, 1959

For the ecological purpose, it is desirable to know, how much dry matter production would be done by leaves of evergreen trees during the winter, and in this view their photosynthetic activity should be measured in that season. Much of the available information concerned with this problem is seen in Zeller's paper ${ }^{1}$. After Allvik's method of colorimetric $\mathrm{CO}_{2}$-measurement, some workers ${ }^{2), 3), t)}$ have investigated the subject whether net photosynthesis of evergreen plants is positive or negative in winter, with particular reference to the effects of frost. On the other hand, approaches were also made by studying the seasonal course of photosynthetic activity and seasonal pattern of dry matter production (Kusumoto ${ }^{5), 6)}$, Saeki and Notomo ${ }^{7}$, Bourdeau ${ }^{8)}$ ), especially detailed studies in Picea excelsa and Pinus cembra were carried out by Pisek and Winkler' ${ }^{9}$.

In the present paper we will elucidate the features of $\mathrm{CO}_{2}$-assimilation of twigs of Chamaecyparis pisifera (Sawara cypress), of which natural distribution is mainly restricted within the temperate region of Honshu, Japan, measured in the winter of 1954, and discuss the dry matter production in that period comparing them with those in spring and summer.

\section{Material and Method}

Sample twigs of Ch. pisifera were taken for each measurement from a hedge, grown from cuttings and about two meters high, at a suburban residential quarter of Tokyo. For this study, two kinds of branches were sampled from a tree, one had changed its leaf color from green to brown and the other kept its original green color throughout the winter.

For measurements of photosynthetic and respiratory rates, a modified Boysen Jensen's method ${ }^{9}$ ) was employed, and the same procedure with Saeki and Nomoto's ${ }^{7}$ was followed for excising sample twigs. The illumination was furnished by a 300 or $500 \mathrm{~W}$ reflector lamp with sky light and the flowing air through the assimilation chamber was regulated at a constant temperature during the experiment. The obtained values were corrected on the basis of 0.03 volume percent $\mathrm{CO}_{2}$. The net and gross photosynthetic rates and the compensation point of each twig were deter-

* Biological Institute, Faculty of Arts and Sciences, Ibaraki University, Mito, Japan. 茨城大学文理学部生物学教室

** Botanical Institute, Faculty of Science, University of Tokyo, Hongo, Tokyo, Japan. 東京大学理学部植物学教室 
mined by defining the light-photosynthesis curve with a series of measurements. The chlorophyll content of leaves, after conversion of extracted chlorophyll into pheophytin, was determined colorimetrically ${ }^{10)}$.

\section{Photosynthetic activity during winter}

As referred previously, some twigs of Ch. pisifera kept on a brown color through the cold winter, and others remained green as ever. The chlorophyll content of these colored and green leaves, measured in the winter of 1954, was summarized in Table 1. During the late winter, from the end of February to early March, the chlorophyll content of the colored leaves was about $0.8 \mathrm{mg}$. per $\mathrm{g}$. fresh weight of leaves, - that is, a half of the content of the green leaves in the same period. The leaves which had been changed in color through the cold months, gradually recovered to green in the spring (cf. Hiramatu ${ }^{12)}$ ), increasing the chlorophyll content again. On the other hand, as to the green leaves whose color has been unchangeable in appearance throughout the winter, it may be said that the hibernal retreatment of chlorophyll content is not so remarkable. New scaly leaves of Ch. pisifera begin to develop late in May and their chlorophyll content increases rapidly until it attains the value of matured one.

Fig. 1 shows the light-photosynthesis curves of those green and colored leaves obtained from late February to early March. The maximum net photosynthetic rate of colored twigs was $0.42 \mathrm{mg}$. $\mathrm{CO}_{2} /$ g. fresh weight $/ \mathrm{hr}$. at $10^{\circ}$ on March 1 , and this was only a half of 0.82 $\mathrm{mg}$. of green ones on February 18 $\left(\right.$ at $\left.10^{\circ}\right)$. Another conspicuous difference between the colored and green leaves was the elevation of light compensation point in the

Table 1. Comparison between chlorophyll contents in colored and green leaves of Chamaecyparis pisifera, in $\mathrm{mg} . / \mathrm{g}$. fresh leaves. (The astericks indicate sprouted leaves).

\begin{tabular}{cc|cc}
\multicolumn{2}{c|}{ Colored leaves } & \multicolumn{3}{|c}{ Green leaves } \\
\hline Feb. 24 & 0.89 & Feb. 25 & 1.65 \\
Feb. 26 & 0.70 & Feb. 26 & 1.62 \\
Mar. 1 & 0.79 & Mar. 3 & 1.45 \\
Apr. 20 & 0.81 & Mar. 5 & 1.99 \\
Apr. 21 & 0.97 & Apr. 12 & 1.38 \\
Apr. 23 & 1.01 & May 6 & 1.97 \\
Apr. 26 & 1.04 & May 7 & 2.11 \\
Apr. 27 & 0.99 & May 10 & 2.19 \\
May 7 & 1.45 & May 13 & 1.79 \\
May 17 & 1.31 & May 15 & 1.89 \\
& $\left(1.08^{*}\right)$ & (1. &
\end{tabular}

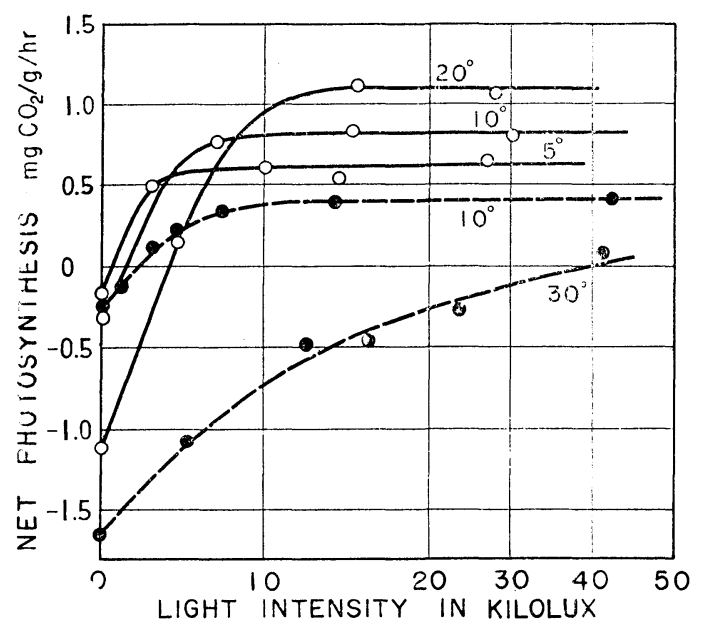

Fig. 1. Light-photosynthesis curves of Chamaecyparis pisifera. Solid lines show the curves of green twigs, obtained from Feb. 18 to Feb. 25, while broken lines those of colored ones, from March 1 to March 11. 
former; that is, the compensation point of the colored leaves was ca. 2,300 lux at $10^{\circ}$, while that of the green ones, ca. 1,500 lux at the same temperature. The higher the temperature, the higher the compensation point, e.g. in the colored leaves at $20^{\circ}$ ca. 8,000 lux of compensation point and at $30^{\circ}$ even 40,000 lux were measured. Pavletić and Lieth ${ }^{3}$ measured colorimetrically the light compensation point in winter in some conifers and evergreen species with a view to compare their frost sensibilities, and they confirmed that even at 3,200 lux, the highest illumination provided so far, there occurred no compensation in twigs of Ch. nootkatensis and some other conifers, suggesting that the compensation point may well be considerably high.

The productivity of the colored leaves in winter is characterized not only by their depressed maximum photosynthesis in saturated illumination, but also by extremely high light compensation point. The latter is partly due to the ineffective light absorption by the brownish pigments which exist in great quantity in chloroplasts of mesophyll, mainly palisade, cells in contrast with heavy chlorophyll decomposition and were confirmed as carotenoids by column-chromatography and spectrophotometry.-Red pigments in the autumnal leaves of conifers have been identified by $\mathrm{Hida}^{13}$ ) as cyanidin and/or delphinidin, besides carotenoids. The above explanation was acertained by the fact that under the light transmitted through a red color filter $\left.(600-700 \mathrm{~m} \mu)^{14}\right)$ the initial inclination of the photosynthetic curve of colored leaves coincided with that of green ones (see Fig. 2).

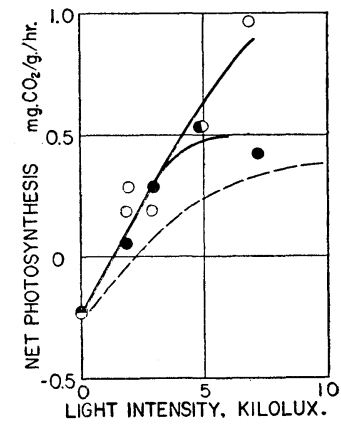

Fig. 2. Net photosynthetic rate of colored (solid circles) and green leaves (open circles) under the light transmitted through a red color filter $(600-700 \mathrm{~m} \mu)$; temperature $10^{\circ}$. Broken line indicates the same curve with that of the colored at the same temperature in Fig. 1.

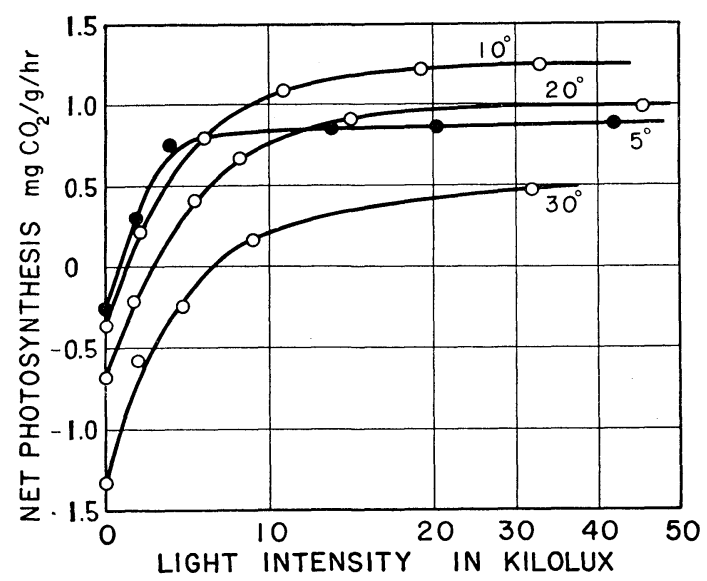

Fig. 3. Light-photosynthesis curves of twigs which had apparently recovered to green from colored condition, obtained from April 23 to April 30.

As the spring advances, the photosynthetic activity of colored leaves has clearly been restored as seen in Picea and Pinus by Pisek and Winkler ${ }^{9}$, with the recovery of chlorophyll content. Curves shown in Fig. 3 were obtained for twigs 
which already recovered apparently from colored condition in the last winter. The steeper slopes of curves in spring agreed with those of the green twigs in Fig. 1.

\section{A comparison of dry matter production in winter with those in other seasons}

The maximum net photosynthesis and respiration of twigs of Ch. pisifera determined in different seasons of the year were summarized in Table 2, excepting those of colored ones in winter. There is shown that the net photosynthetic rates measured at $20^{\circ}$ and under saturated light condition increased from spring to summer, up to its maximum level in August, then markedly decreased in October. This

Table 2. Maximum net photosynthesis $(a-r)$ and respiration $(\boldsymbol{r})$ in $\mathrm{mg} . \mathrm{CO}_{2} / \mathrm{g}$. fresh twigs/hr., and the ratio of $a / r$, of Chamaecyparis pisifera.

\begin{tabular}{|c|c|c|c|c|c|c|c|c|c|c|c|c|c|c|c|c|c|c|}
\hline & \multicolumn{3}{|c|}{ Fieb. } & \multicolumn{3}{|c|}{ Apr. } & \multicolumn{3}{|c|}{ May } & \multicolumn{3}{|c|}{ Jul. } & \multicolumn{3}{|c|}{ Aug. } & \multicolumn{3}{|c|}{ Oct. } \\
\hline & $a-r$ & $r$ & $a / r$ & $a-r$ & $r$ & $a / r$ & $a-r$ & $r$ & $a / r$ & $y-r$ & $r$ & $a / r$ & $a-r$ & $r$ & $a / r$ & $a-r$ & $r$ & $a / r$ \\
\hline 5 & 0.7 & 0.2 & 4.5 & 0.9 & 0.2 & 5.5 & 一 & - & - & - & - & - & - & - & - & - & - & - \\
\hline 10 & 0.8 & 0,3 & 3.7 & 1.3 & 0.4 & 4.3 & 1.5 & 0.2 & 8.5 & - & - & - & - & - & - & - & - & - \\
\hline 20 & 1. 1 & 1. 2 & 1.9 & 1. 0 & 0.7 & 2.4 & 1.6 & 0.5 & 4. 2 & 2.3 & 0.8 & 3.9 & 2.7 & 0.5 & 6.4 & 1. 2 & 0.4 & 4. 0 \\
\hline $30^{\circ}$ & 0.8 & 2.3 & 1.3 & 0.5 & 1.3 & 1. 4 & - & - & - & - & - & - & - & - & - & - & - & - \\
\hline
\end{tabular}

would give an impression that the duration of high activity in Sawara cypress is considerably shorter than those of Norway spruce and blue spruce examined by Bourdeau $^{8)}$. But, this trend is practically the same as that observed by Saeki and Nomoto in some deciduous and evergreen broad-leaf trees in Japan ${ }^{7}$.

As mentioned above, the net photosynthetic rate in Ch. pisifera twigs was positive during the winter, even though it was at very low level, that is, about one third of those of the growing season. The net amount of dry matter produced by the photosynthetic system is determined by the balance of the income by photosynthesis over the expense by respiration in leaves in a given duration of time. Provided symbol $p$ is the amount of organic matter produced by unit weight of leaves or twigs per day, it is, though approximately, shown by an equation

$$
p=\left(a_{t} \tau-24 r_{t}\right) \mathrm{C}_{6} \mathrm{H}_{10} \mathrm{O}_{5} / 6 \mathrm{CO}_{2}
$$

where $a_{t}$ and $r_{t}$ are the gross photosynthetic and the respiratory rate of leaves or excised twigs at temperature $t^{\circ}$ respectively, and $\tau$ is the photosynthetic hour. The daily production of $C h$. pisifera twigs calculated based on the obtained results is shown in Table 3. For convenience of calculation, here the mean day length of three days, 1st, 11th and 21st, of respective months was applied to $\tau$. From the Table 3 it is demonstrated that, in February the estimated productivity of green twigs is down below zero in higher temperature than $20^{\circ}$, in spite of its relatively high positive net photosynthetic rate, for the sake of the extremely high nocturnal respiration compared with the photosynthesis (see Table 2). It is of interest that the positive productivity of twigs during winter occurs only in the case of moder- 
Table 3. The daily dry matter production, mg. $\mathrm{C}_{6} \mathrm{H}_{10} \mathrm{O}_{5} / \mathrm{g}$. fresh green twigs, in respective months.

\begin{tabular}{c|rrrrrr} 
& Feb. & Apr. & May & Jul. & Aug. & Oct. \\
\hline $\begin{array}{c}\text { Day length in hrs. } \\
\text { Mean monthly temperature }{ }^{\circ} \mathrm{C}\end{array}$ & 10.9 & 13.1 & 14.0 & 14.3 & 13.5 & 11.9 \\
\hline $5^{\circ}$ & 3.9 & 12.8 & 17.2 & 25.1 & 26.4 & 16.4 \\
$10^{\circ}$ & 3.1 & 5.5 & - & - & - & - \\
$20^{\circ}$ & 3.1 & 7.7 & 12.0 & - & - & - \\
$30^{\circ}$ & -2.1 & 3.4 & 10.2 & 15.2 & 19.3 & 5.3 \\
& -12.7 & -5.3 & - & - & - & -
\end{tabular}

ately lower temperature, and such low winter temperature is rather ordinary in Tokyo, as the mean monthly air temperatures of December, January and February are $5.7,3.2$ and $3.9^{\circ}$, respectively. Therefore, it is reasonable to assume that the daily production of green twigs in winter can reach upward of one sixth of that in summer, under the best conditions for dry matter production in respective sersons. On such an occasion in early March, the value of colored twigs fell to 1.3 $\mathrm{mg}$. dry matter/g. fresh weight/day at $10^{\circ}$, - this is only one fifteenth of summer productivity.

The water content of sample twigs was about 55-60 per cent of fresh weight. Thus, it may be said that the green twigs can produce ca. 0.7 per cent dry matter of their own dry weight on a sunny and moderately cold day of winter, while the highest value on a summer day amounts to 4.5 per cent.

\section{Summary}

Photosynthetic activity and dry matter production during winter were investigated in the excised twigs of Sawara cypress Chamaecyparis pisifera, compared with those in the other seasons.

1. In winter, the chlorophyll content of colored leaves of this conifer, which were brown in appearance, had been reduced by half of that of the leaves remaining in green.

2. Net photosynthetic rate of green twigs in winter was positive, though it was at a low level of one third of summer rate. The colored twigs showed more remarkably depressed net photosynthetic rate, and their light compensation point ascended markedly.

3. A positive productivity of green twigs in winter can be observed only in the case of moderately low temperature; under an optimal condition in winter, it was estimated at $3.1 \mathrm{mg}$. dry matter/g. fresh weight/day, i. e. about one sixth of summer maximum productivity. The colored leaves could have a productivity of only one fifteenth of the summer value. 


\section{References}

1) Zeller, O., Planta $39: 500$ (1951). 2) Walter, H., Ber. dtsch. Bot. Ges. $62: 47$ (1949). 3) Pavletić, Z. and Lieth, H., ibid. 71: 188 (1958). 4) Pisek, A. and Rehner, G., ibid. 71: 188 (1958). 5) Kusumoto, T., Jap. Journ. Ecol. 7: 126 (1957). 6) — Bot. Mag. Tokyo 70 : 299 (1957). 7) Saeki, T. and Nomoto, N., ibid. 71 : 235 (1958). 8) Bourdeau, P. F., Ecology 40 : 63 (1959). 9) Pisek, A. and Winkler, E., Planta $51: 518$ (1958). 10) Boysen Jensen, P., Stoffproduktion der Pflanzen, Jena (1932). 11) Kasanaga, H. and Monsi, M., Jap. Journ. Bot. 14: 304 (1954). 12) Hiramatu, K., Ecol. Rev. 3: 295 (1937). 13) Hida, M., Bot. Mag. Tokyo 71 : 425 (1958). 14) Takagi, I., Research Bull. Imp. Tokyo Sericult. Coll. 2: No. 2.11 (1940).

摘 要

サワラの切枝について冬期の光合成が測定され, またその物質生産が春から夏にかけての値と比較され ながら論ぜられた。冬にサワラは葉を褐色に変色しているものと緑色のままのものとがあるが, 前者の Chlorophyll 含量は後者の約 $1 / 2$ であつた。冬の見かけの光合成速度は緑色葉では 2 月中旬に実験温度 $10^{\circ}$, 光飽和のもとで $0.82 \mathrm{mg} . \mathrm{CO}_{2} / \mathrm{g}$. (生量) $/ \mathrm{hr}$. で 8 月の最大值の約 $1 / 3$ であつた。褐色葉では最大 光合成速度がさらにいちじるしく低下していると同時に補償点が極端に高くなつているととが確かめられ た。

舆なつた季節におけるサワラ同化器官の 1 日の物質生産をそれぞれ一定の温度条件で得られた光・光合成 曲線にもこずいて算出すると, 緑色葉では冬期の見かけの光合成がかなり広い温度範囲で正の值を示してい るにもかかわらず, 正の物質生産の可能なのは $10^{\circ}$ 附近の比較的低い温度条件下のみに限られているてとが わかつた。冬の最適条件下でサワラの緑葉 $1 \mathrm{~g}$ は 1 日に $3.1 \mathrm{mg}$. の物質生産を行なうことができるが，て れは憂の最大值のほほ $1 / 6$ である。さらに褆色葉ではての值は約 $1 / 15$ に低下している。 